\title{
Pendampingan Ibu-Ibu PKK Kecamatan Lowokwaru Malang melalui Pelatihan Pembuatan Pestisida Nabati sebagai Pengendalian Hama Sayuran Hidroponik
}

\author{
Liliek Harianie ${ }^{1}$, Shinta ${ }^{2}$, Lila Biarrohmah³, Lina Hidayatur Rohmah³, \\ Widya Maslahah ${ }^{3}$ \\ 1, 2,3 Universitas Islam Negeri Maulana Malik Ibrahim Malang, Indonesia
}

\begin{abstract}
A B S T R A C T
GUIDING OF PKK MOTHERS IN LOWOKWARU MALANG DISTRICT THROUGH TRAINING FOR MAKING VEGETABLE PESTICIDES AS A CONTROL OF HYDROPONIC VEGETABLE PEST. In general, chemical pesticides are used to eradicate pests in vegetables. That is because many chemical pesticides are sold in the market and very effective in eradicating pests. The users of chemical pesticides do not understand, if the use of chemical pesticides for a long time and continuously will be very dangerous. Steps that can be taken to prevent the dangers of chemical pesticides is using natural or vegetable pesticides. Vegetable pesticides are more environmentally friendly, the prices are much cheaper, and not dangerous, and the manufacturing process is very easy. The social role of PKK mothers is carried out to improve the activities of coaching, education, training, and counseling. Therefore, it is necessary to conduct socialization and training in the manufacture of plant-based pesticides for PKK mothers in Lowokwaru District, Malang. The methods used include counseling through lectures, direct practice of making vegetable pesticides, and evaluating the process of making vegetable pesticides. The results of a survey of partners showed that $63 \%$ of PKK present did not know about vegetable pesticides. In addition, $81 \%$ of partners before participating in training activities had never been aware of the process of making vegetable pesticides. Around $90 \%$ of partners are known to have never participated in training in making vegetable pesticides. After participating in training and practice in making vegetable pesticides, it is known that $100 \%$ of the community service partners have stated that they can increase their knowledge, skills and practice by making vegetable pesticides at home.
\end{abstract}

Keywords: Lowokwaru District, PKK Mothers, Training, Vegetable Pesticides.

\begin{tabular}{llll}
\hline Received: & Revised: & Accepted: & Available online: \\
11.10 .2019 & 11.01 .2020 & 29.01 .2020 & 14.02 .2020 \\
\hline
\end{tabular}

\section{Suggested citation:}

Harianie, L., Shinta., Biarrohmah, L., Rohmah, L. H., \& Maslahah, W. (2020). Pendampingan ibuibu PKK Kecamatan Lowokwaru Malang melalui pelatihan pembuatan pestisida nabati sebagai pengendalian hama sayuran hidroponik. Jurnal Pengabdian Pada Masyarakat, 5(1), 175-184. https://doi.org/10.30653/002.202051.274

Open Access I URL: http://ppm.ejournal.id/index.php/pengabdian/article/view/274

${ }_{2}$ Corresponding Author: Sintha: Universitas Islam Negeri Maulana Malik Ibrahim Malang. Jl. Gajayana No.50, Dinoyo, Kec. Lowokwaru, Kota Malang, Jawa Timur 65144, Indonesia. Email: shinta.sakura88@gmail.com 


\section{PENDAHULUAN}

Sayuran banyak digemari masyarakat karena sayuran merupakan sumber vitamin, mineral, protein, nabati, dan serat. Kebutuhan sayuran yang terus meningkat di masyarakat tidak didukung dengan luas lahan yang digunakan untuk penanamannya. Salah satu solusi yang dapat digunakan yaitu menerapkan sayuran hidroponik. Sayuran hidroponik adalah sayuran yang ditanam tanpa menggunakan media tanam tanah melainkan menggunakan media tanam air dengan campuran hara (Rosliani \& Sumarni, 2005). Sayuran hidroponik dibudidayakan di Indonesia untuk memenuhi kebutuhan sayuran dengan kualitas tinggi secara kontinyu. Data kementerian pertanian tahun 2014 bahwa lahan pertanian di Indonesia mengalami penurunan sejak Tahun 2012-2013 sebesar 11,37\% dan telah mengalami penurunan tingkat kesuburan tanah sejak 30 tahun lalu. Oleh karena itu, sayuran hidroponik merupakan salah satu solusi untuk mengatasi permasalahan tersebut.

Pada pengabdian sebelumnya tahun 2018, sudah dilakukan pendampingan pelatihan budidaya hidroponik ibu-ibu PKK di Kecamatan Lowokwaru Kota Malang. Selain itu, juga dilakukan penanaman sayuran hidroponik dengan sistem NFT di kantor Kecamatan Lowokwaru, namun sayuran banyak terserang hama. Masalah utama dalam budidaya sayuran hidroponik adalah hama dan penyakit, Serangan hama atau penyakit seringnya terjadi pada saat tanaman sudah mulai tumbuh daun dan batang.

Tanaman yang terserang hama yaitu daun dan buah berlubang lalu membusuk atau mati. Gangguan dari hama dan penyakit dapat menurunkan kualitas dan rendahnya produktivitas tanaman. Jenis hama yang menyerang tanaman sayuran hidroponi, antara lain; ulat, semut, lalat buah, thrips, tungau tanaman (mite), kutu kebul (Bemisia tabaci) penggorok daun dan belalang (Suhartini, Suryadarma, \& Budiwati, 2017).

Pada umumnya, masyarakat membasmi hama yang menyerang sayuran menggunakan pestisida kimia. Hal tersebut dikarenakan pestisida kimia banyak dijual di pasaran dan sangat efektif dalam membasmi hama. Mereka tidak mengerti jika akibat yang ditimbulkan dari penggunaan pestisida kimia dalam jangka waktu lama dan terusmenerus sangat berbahaya. Petani masih menggunakan pestisida sintetis (non nabati) dalam pengendalian hama tanaman dengan alasan mudah didapat dan efektif, tetapi mempunyai dampak negatif bagi lingkungan (Aji, Bahri, \& Raihan, 2016).

Pestisida kimia ini tidak dapat terurai di alam sehingga residunya akan terakumulasi dalam tanah. Selain menempel di sayuran, jika senyawa ini ikut terkonsumsi bersama sayuran yang kita makan, maka akan sangat berbahaya karena sifatnya yang toksik dan dapat menyebabkan berbagai penyakit degeneratif seperti kanker. Sementara, pestisida yang terakumulasi dalam tanah dapat menyebabkan kerusakan tanah dan resistensi pada hama (Deden, 2017).

Salah satu alternatif untuk menanggulangi tingginya serangan hama yaitu dengan menggunakan pestisida nabati (Aji, Bahri, \& Raihan, 2016). Jika dibandingkan dengan pestisida kimia, maka pestisida nabati mempunyai beberapa kelebihan. Salah satu kelebihannya yaitu lebih ramah lingkungan dan tidak menyebabkan kerusakan tanah.

Menurut Saenong (2016) menyatakan bahwa keunggulan pestisida nabati yaitu pertama, lebih ramah terhadap alam, karena sifat material organik mudah terurai menjadi bentuk lain, sehingga dampak racunnya tidak menetap dalam waktu yang lama di alam bebas. Kedua, residu pestisida nabati tidak bertahan lama pada tanaman, 
sehingga tanaman yang disemprot lebih aman untuk dikonsumsi. Ketiga, dilihat dari sisi ekonomi, penggunaan pestisida nabati memberikan nilai tambah pada produk yang dihasilkan. Produk pangan non pestisida harganya lebih baik dibanding produk konvensional. Selain itu, pembuatan pestisida nabati bisa dilakukan sendiri, sehingga menghemat pengeluaran biaya produksi. Keempat, penggunaan pestisida nabati yang diintegrasikan dengan konsep pengendalian hama terpadu tidak akan menyebabkan resistensi pada hama.

Berdasarkan pernyataan di atas, maka dilakukan survei terhadap masyarakat tentang pengetahuan mereka terhadap pestisida nabati. Namun, terungkap bahwa belum banyak masyarakat yang menyadari bahaya yang ditimbulkan akibat penggunaan pestisida kimia dalam jangka waktu yang lama. Mereka juga belum mengetahui adanya pestisida organik atau nabati yang jauh lebih murah dan tidak berbahaya dimana proses pembuatannya sangat mudah. Dengan demikian, maka perlu dilakukan sosialisasi dan pemberian ketrampilan pembuatan pestisida nabati yang ramah lingkungan untuk mengatasi serangan hama pada tanaman sayuran hidroponik. Melalui pelatihan ini, diharapkan nilai mengahasilkan tanaman sayuran hidroponik yang sehat bebas hama, pencemaran lingkungan berkurang dan mengurangi timbulnya penyakit-penyakit degeneratif yang disebabkan oleh penggunaan pestisida kimia.

\section{METODE}

Subjek dampingan dalam kegiatan pengabdian masyarakat ini adalah perwakilan Ibu-Ibu PKK dari 12 kelurahan di Kecamatan Lowokwaru, Kota Malang. Ibu-Ibu PKK merupakan bagian masyarakat yang aktif dalam kegiatan masyarakat. Peran sosial IbuIbu PKK dapat ditingkatkan melalui kegiatan pembinaan, pendidikan, pelatihan dan penyuluhan (Sukidjo, 2000). Tahapan awal yang dilakukan adalah dengan melakukan survei atau tahap identifikasi pada subjek dampingan yang dilaksanakan pada bulan September 2019. Langkah ini diperlukan untuk menganalisis masalah mitra dampingan serta mendata kelompok PKK yang dilibatkan sebagai mitra pengabdian masyarakat. Pelaksanaan pengabdian masyarakat dilakukan pada bulan September sampai Oktober 2019 secara periodik. Metode yang dipilih dalam kegiatan pengabdian masyarakat yaitu metode pelatihan yang meliputi kegiatan penyuluhan melalui ceramah, praktik langsung pembuatan pestisida nabati, diawali dengan demo oleh narasumber diikuti oleh mitra dampingan lalu dilakukan evaluasi dari hasil pembuatan pestida nabati. Rangkaian proses pelatihan sebagai berikut:

\section{Tahap 1. Penyuluhan}

Penyuluhan dilakukan melalui ceramah dari narasumber. Tujuannya adalah untuk meningkatkan wawasan mitra mengenai produk. Media yang digunakan untuk ceramah adalah power point dan leaflet atau brosur berisi definisi, manfaat dan alur kerja pembuatan pestisida nabati. Penggunaan media pendukung dalam ceramah diharapkan mampu meningkatkan pemahaman mitra dampingan. Pelaksanaan ceramah selama 30 menit. Sesi tanya jawab juga disediakan selama proses ceramah. 


\section{Tahap 2. Demonstrasi dan Praktik}

Tahap ini dilakukan untuk memberikan gambaran nyata proses pembuatan pestisida nabati sehingga mitra dampingan memahami tidak hanya teori namun juga mempraktikkan langsung dengan mengetahui alat, bahan dan proses yang digunakan dalam pembuatan pestisida nabati. Pengajar dalam hal ini berperan sebagai mediator karena: apa yang dipelajari oleh peserta, bukan apa yang diajarkan oleh pengajar merupakan hal penting dalam pendidikan orang dewasa (Sudjarwo, 2011).

Pada tahap ini mitra diajarkan dan dikenalkan dua jenis pestisida dengan bahan yang berbeda: bahan pestisida yang pertama sebagai berikut : Terdiri dari bahan utama: air, kunyit putih, kunyit kuning, jahe, temulawak, lengkuas, gula merah cabe, bawang putih, dan bahan perekat labu siam serta bahan perasa pahit mrnggunakan dau paitan. Bahan pestisida kedua yaitu jahe, lengkuas, bawang putih, daun kacang babi, daun nimba dan labu Siam.

\section{Tahap 3. Evaluasi}

Tahap evaluasi dilakukan untuk mengukur tingkat pemahaman mitra dampingan melalui kuisioner serta menjadi evaluasi bagi narasumber untuk kegiatan pendampingan selanjutnya. Evaluasi akan dilaksanakan selama dan setelah pelaksanaan kegiatan penyuluhan dan pelatihan. Selama pelaksanaan kegiatan dilakukan evaluasi dengan metode pengamatan langsung oleh Tim Pengabdian. Sedangkan setelah pelaksanaan kegiatan dilakukan evaluasi dengan metode pengamatan terhadap hasil kegiatan dan metode angket atau kuisioner. Kriteria evaluasi meliputi kasadaran dan antusiasme peserta pelatihan dalam mengikuti kegiatan serta tingkat kemahiran peserta dalam mempraktikkan.

\section{HASIL DAN PEMBAHASAN}

Hasil survei yang dilakukan pada Ibu-Ibu PKK Lowokwaru, Malang disepakati untuk mengadakan kegiatan pengabdian masyarakat dengan mitra Ibu-Ibu PKK pada Bulan Oktober 2019. Kegiatan pengabdian ini dilakukan di Kecematan lowokwaru yang dihadiri perwakilan ibu-bu PKK dari 12 Kelurahan Kecamtan Lowokwaru Kota Malang. Kegiatan pengabdian diikuti oleh 30 orang, 84\% mitra adalah ibu rumah tangga, $10 \%$ wiraswasta, $3 \%$ pensiunan dan $3 \%$ pegawai swasta dengan karakteristik usia antara masa dewasa akhir (35-45 tahun) sampai masa lansia akhir ( $>57$ tahun) (Gambar 1).

Ibu-ibu PKK atau Mitra pengabdian sebagain besar adalah ibu rumah tangga dengan karakteristik usia pada masa dewasa sampai lansia sangat tepat mendapatkan materi mengenai pembuatan pestisida nabati untuk meningkatkan kreativitas mitra dalam membuat pestisida nabati dari bahan-bahan alami yang mudah diperoleh di lingkungan sekitar. 


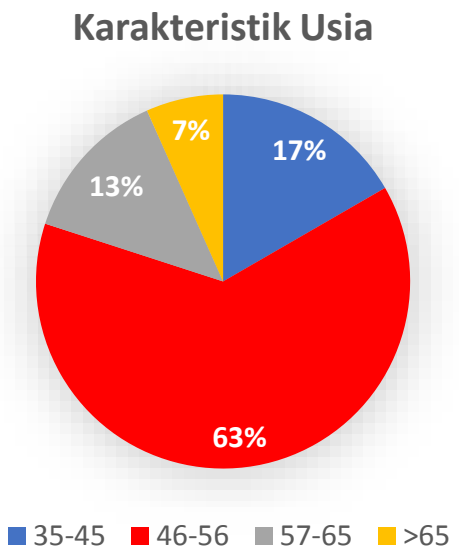

\section{Gambar 1. Karakteristik Usia Mitra Pengabdian}

Sumber: Hasil kuisioner pada mitra

\section{Persiapan penyuluhan dan pelatihan}

Kegiatan ini berupa penentuan Bahan yang digunakan dalam pembutan pestisida nabati, pembuatan modul penyuluhan dan pelatihan. Modul penyuluhan berisi materi dasar tentang tinjauan tentang pestsida nabati, hama sayuran, macam-macam pestisida nabati, bahan yang digunakan dalam pestisida nabati serta langkah-langkah dalam pembuatan pestisida nabati. Pada persiapan pelatihan, Tim pengabdian melakukan uji coba di laboratorium, sehingga didapatkan komposisi dan bahan yang tepat dan memberikan hasil optimal dalam pembuatan pestisida nabati (Gambar 2).

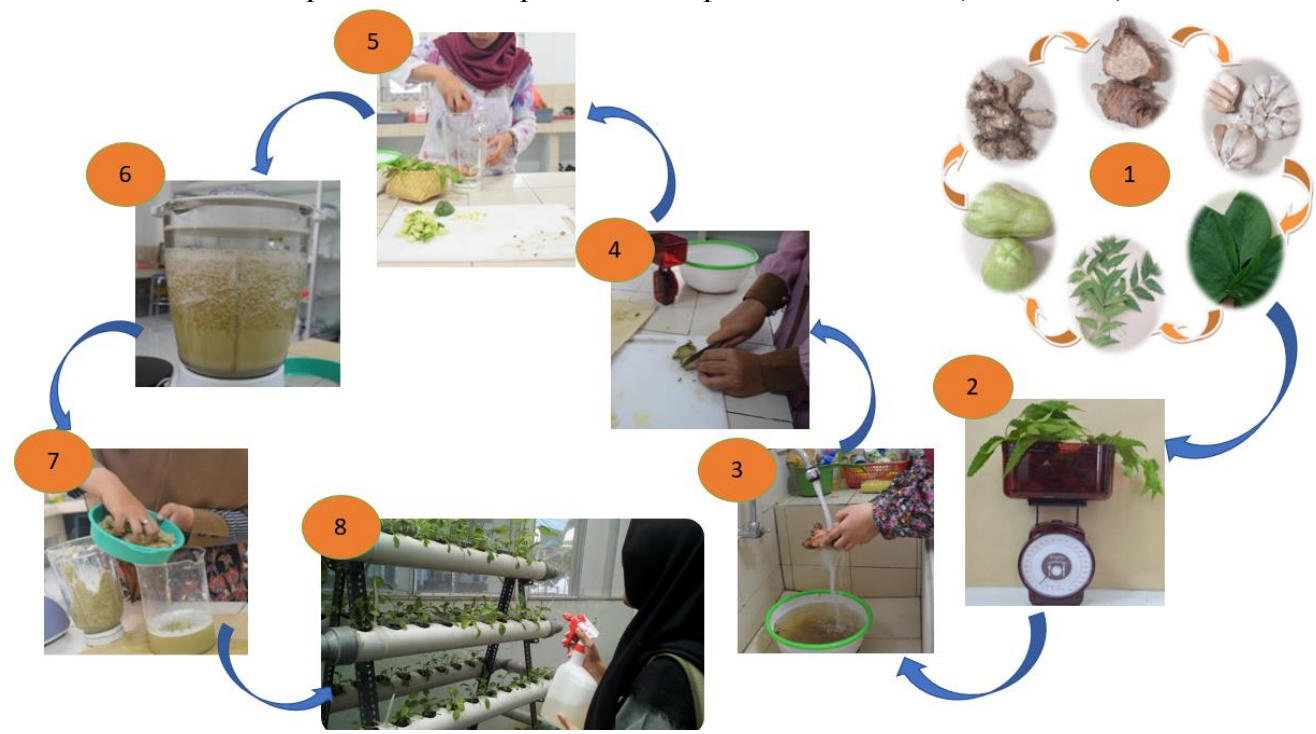

Gambar 2. Tahapan Percobaan Pembuatan Pestisida Nabati Sumber: Dokumentasi Pribadi, 2019

Keterangan: 1) disiapkan bahan, 2) bahan ditimbang, 3) bahan dicuci bersih dari kotoran, 4) bahan dirajang, 5) dan 6) proses penhalusan, 7) proses pemisahan saripati 
dengan cara diperas dan diisaring 8) pestisida nabati diaplikasikan ke sayuran hidroponik.

\section{Pelaksanaan Penyuluhan dan Pelatihan}

Penyuluhan diadakan di Kecematan lowokwaru yang dihadiri perwakilan ibu-bu PKK dari 12 kelurahan di Kecamatan Lowokwaru Kota Malang. Beberapa kegiatan yang dilakukan adalah sebagai berikut: Metode pendampingan berupa ceramah dan edukasi mengenai 1) definisi dan proses pembuatan pestisida nabati, 2) langkahlangkah pembuatan pestisida nabati yang didukung media leaflet agar memudahkan mitra memahami materi yang diberikan (Gambar 3). Kombinasi metode ceramah dengan edukasi dan penggunaan media merupakan variasi metode dalam penyampaian materi kepada masyarakat sehingga peserta tidak jenuh atau bosan (Djamarah, 2000). Selanjutnya dilanjutkan dengan praktik langsung dan tanya jawab.

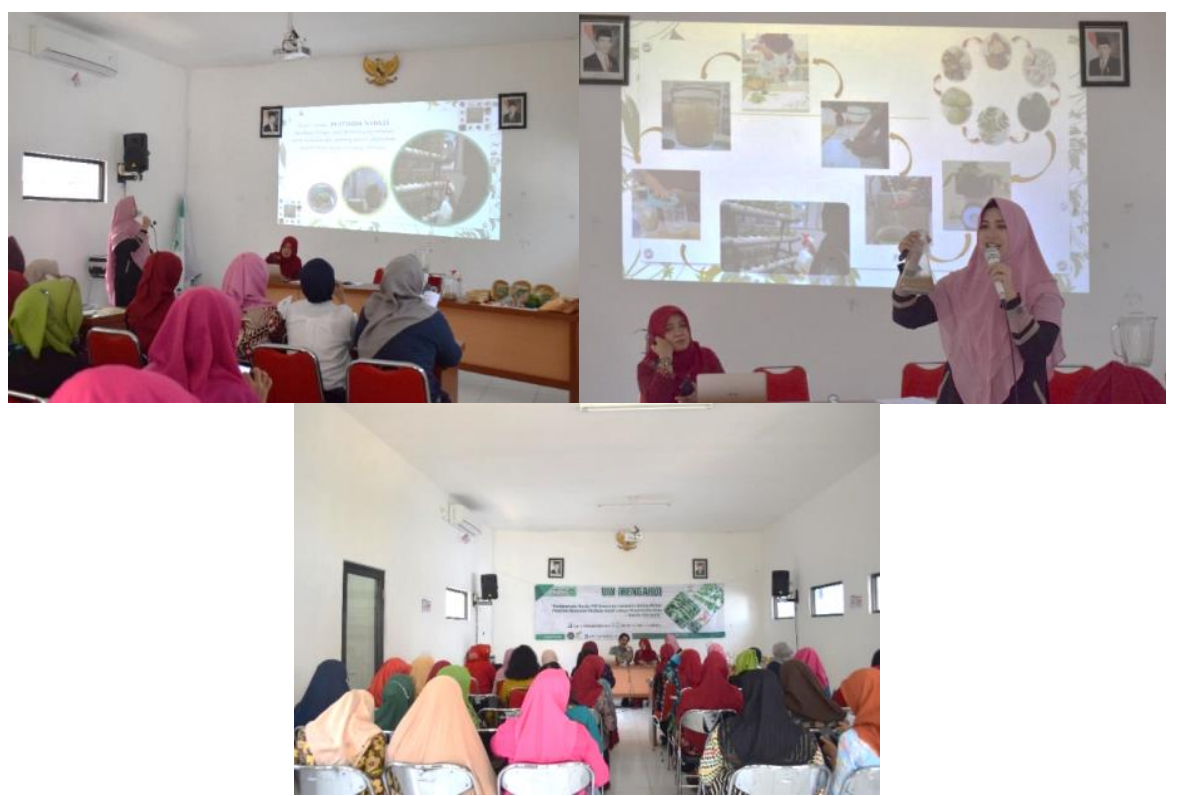

Gambar 2. Penyampaian Materi dengan Metode Ceramah dan Edukasi kepada Mitra

Ceramah dan edukasi (teori maupun praktik) dalam pembuatan pestisida nabati, meliputi, definisi pestisida nabati, proses pembuatan pestisida nabati. Menurut Deden (2017) pestisida nabati adalah pestisida yang berasal dari tumbuhan, sedangkan arti pestisida itu sendiri adalah bahan yang dapat digunakan untuk mengendalikan populasi Organisma Pengganggu Tanaman (OPT). Pestisida nabati bersifat mudah terdegradasi di alam (Bio-degredable), sehingga residunya pada tanaman dan lingkungan tidak signifikan. Indonesia di kenal dengan negara yang memiliki kekayaan keanekaragaman hayati (Mega-biodiversity) terbesar kedua di dunia setelah Brazil, termasuk memiliki sejumlah tanaman yang dapat digunakan sebagai bahan dasar pestisida, baik yang dapat langsung digunakan atau dengan ekstraksi sederhana dengan air, ekstraksi dengan pelarut organik lainnya ataupun dengan cara penyulingan, tergantung kepada tujuan dari formula yang akan dibuat.

Pestisida nabati merupakan suatu pestisida yang dibuat dari tumbuh-tumbuhan yang residunya mudah terurai di alam sehingga aman bagi lingkungan dan kehidupan 
makhluk hidup lainnya. Tumbuhan yang dapat digunakan sebagai pestisida nabati antara lain, kunyit, tembakau, mimba, mindi, mahoni, srikaya, sirsak, tuba, dan juga berbagai jenis gulma seperti babandotan (Samsudin, 2008). Teknik pengendalian hama menggunakan pestisida nabati yang merupakan pengendalian hama terpadu diharapkan dapat menciptakan lingkungan yang aman. Pestisida nabati memiliki berbagai fungsi seperti: Repelan atau penolak serangga misalnya bau menyengat yang dihasilkan tumbuhan. Antifidan atau penghambat daya makan serangga atau menghambat perkembangan hama serangga. Atraktan atau penarik kehadiran serangga sehingga dapat dijadikan tumbuhan perangkap hama (Suryaningsih \& Hadisoeganda, 2004).

Maka dari itu alternatif pemanfaatan pestisida nabati yang berasal dari tanaman sangat penting dalam pengendalian hayati untuk menuju pertanian yang berwawasan lingkungan. Pestisida nabati sebenarnya merupakan kearifan lokal bangsa Indonesia, karena banyak masyarakat yang sudah mengetahui jenis tanaman yang dapat digunakan untuk mengendalikan hama tanaman, namun kurang dikembangkan, sementara Indonesia kaya akan keanekaragaman hayati. Oleh karena itu, penggunaan pestisida nabati di Indonesia perlu diperkenalkan terhadap pengguna, serta disosialisasikan dan didiseminasikan kepada semua para pemangku kepentingan (Stake holder).

\section{Praktik Pembuatan Pestisida Nabati}

Tahap praktik atau demonstasi yaitu mengajak mitra dalam pembuatan pestisida nabati, Setelah itu disampaikan dan dipraktikkan mitra pengabdian. Hasil survei terhadap mitra menunjukkan bahwa 36,7\% ibu-ibu PKK yang hadir telah mengetahui mengenai pestisida nabati, sedangkan $63,3 \%$ mitra belum mengetahui tentang pestisida nabati. Disamping itu juga, $81,1 \%$ mitra belum mengetahui proses prmbuatan pestisida. Selai itu juga, 90\% mitra belum pernah mengaplikasikan dan mengikuti pelatihan pembuatan pestisida nabati. Oleh karena itu perlu pendampingan dan pelatihan pembuatan pestisida nabati dalam bentuk praktik langsung ke mitra.

Adapun prosedur dalam pembuatan pestisida nabati dibuat dua macam pestisida. Cara pembuatan pestisida pertama melalui tahap sebagai berikut: 1) bahan utama yang digunakan adalah: kunyit putih, jahe, kunyit kuning, temulawak, lengkuas, gula merah, cabai, bawang putih, bahan perekat labu siam dan bahan perasa pahit menggunakan daun paitan (masing-masing bahan ditimbang $100 \mathrm{~g}$ ). Langkah pembuatan pestisida nabati yang pertama: diawali dengan merajang ssemua bahan. Bahan yang telah dirajang diblender atau ditumbuk hingga halus. Ampas yang didapat dipisahkan dengan saripatinya dengan cara diperas atau disaring. Saripati yang didapatkan didiamkan selama 24 jam. Pestisida alami satu siap diaplikasikan dengan cara diencerkan. Saripati $125 \mathrm{ml}$ diencerkan dalam 1 liter air. Aplikasi pestisida ini dilakukan dengan segera sebelum bahan alami yang terkandung dalam pestisida tersebut rusak.

Bahan pestisida nabati yang kedua yaitu jahe $3 \mathrm{~kg}$, lengkuas $3 \mathrm{~kg}$, bawang putih 3 $\mathrm{kg}$, daun kacang babi, daun mimba, buah labu siam $2 \mathrm{~kg}$ (sebagai perekat) dan Air $10 \mathrm{~L}$. tahapan pembuatannya yaitu dengan cara, merajang semuaa bahan, kemudian dihaluskan semua bahandengan cara diblender atau ditumbuk, kemudian dicampur dengan air bersih $10 \mathrm{~L}$, diaduk hingga rata lalu disaring. Diambil 10-15 ml larutan 
pestisida yang sudah dibuat kemudian campur dengan $1 \mathrm{~L}$ air. Kemudian Semprotkan pada tanaman yang terkena hama.

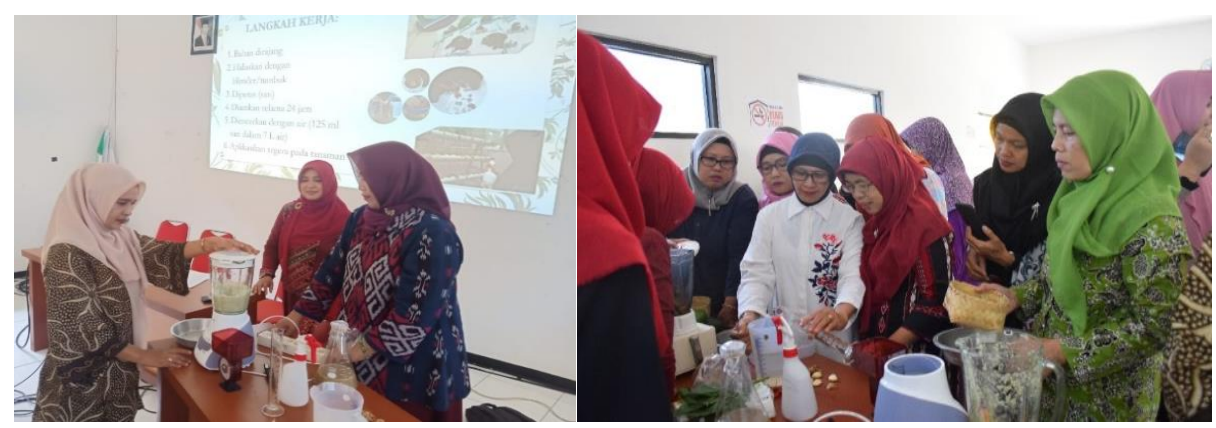

Gambar 3. Praktik Pembuatan Nata dengan Mitra Pengabdian

\section{Evaluasi Kegiatan}

Evaluasi kegiatan diperoleh dari hasil kuisioner mitra dampingan yang memberikan tanggapan terhadap pertanyaan mengenai ppestisida nabati (Gambar 4). Sekitar 57\% mitra dampingan setuju bahwa pembuatan pestisida nabati dapat dilakukan di rumah, sisanya menyatakan sangat setuju. Sebanyak $53 \%$ responden setuju jika biaya produksi pestisida nabati terjangkau, sisanya menyatakan sangat terjangkau.

Enam puluh persen responden menyatakan setuju jika alat dan bahan dalam proses pembuatan pestisida nabati mudah diperoleh dan $40 \%$ responden menyatakan sangat setuju, terutama bahan sepaerti unyit putih, jahe, kunyit kuning, temulawak, lengkuas, gula merah, cabai, bawang putih, bahan perekat labu siam, daun paitan, bawang putih mudah diperoleh dilingkungan sekitar di kota Malang. Kemudian tanggapan mengenai pembutan pestsida dapat menumbuhkan kreativitas $57 \%$ setuju, sisanya menyatakan sangat setuju. Mitra dapat berkreativitas mengolah membuat pestisida nabati dari bahan-bahan tumbuh-tumbuhan disekitar lingkungan tempat tinggal.

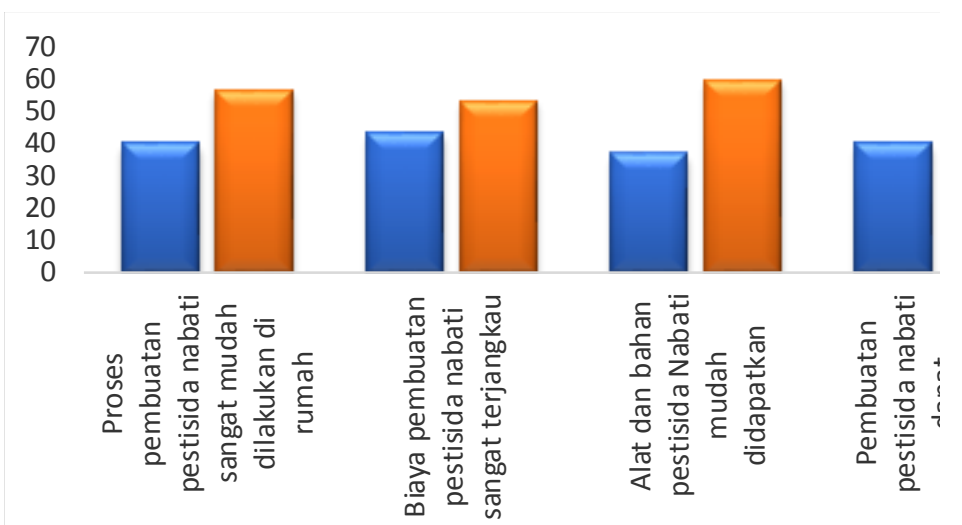

Gambar 4. Tanggapan Responden tentang Pembuatan Pestisida Nabati 


\section{SIMPULAN}

Peran sosial PKK dapat ditingkatkan melalui kegiatan pembinaan, pendidikan, pelatihan dan penyuluhan, salah satunya adalah pelatihan pembuatan pestisida nabati. Metode yang digunakan meliputi kegiatan penyuluhan melalui ceramah, praktik langsung pembuatan pestisida nabati kemudian dilakukan evaluasi dari proses pembuatan pestisida nabati. Hasil survei terhadap mitra menunjukkan bahwa $63 \%$ PKK yang hadir belum mengetahui mengenai pestisida nabati. Selain itu, $81 \%$ mitra sebelum mengikuti kegiatan pelatihan, belum pernah mengetahui proses pembuatan pestisida nabati. Sekitar 90\% mitra diketahui belum pernah mengikuti pelatihan pembuatan pestisida nabati. Setelah mengikuti pelatihan dan praktik pembuatan pestisida nabati, diketahui $100 \%$ mitra pengabdian menyatakan dapat menambah pengetahuan, keterampilan, dan dapat mempraktikkan sendiri pembuatan pestisida nabati di rumah

\section{Ucapan Terimakasih}

Terima kasih kepada Lembaga Penelitian dan Pengabdian Kepada Masyarakat (LP2M) UIN Maulana Malik Ibrahim Malang yang memberikan hibah pendanaan melalui program UIN Mengabdi 2019.

\section{REFERENSI}

Aji, A., Bahri, S., \& Raihan, S. (2016). Pembuatan pestisida dari daun kerinyu dengan mengunakan sabun colek dan minyak tanah sebagai bahan pencampur (Active ingredients). Jurnal Teknologi Kimia Unimal, 5(2), 8-18.

Deden. (2017). Efektivitas pestisida nabati terhadap pengendalian ulat grayak (Spodoptera sp.) pada tanaman sawi (). Jurnal Logika, 14(1).

Djamarah, S. B. (2000). Guru dan anak didik dalam interaksi edukatif. Jakarta: Rineka Cipta.

Rosliani, R., \& Sumarni, N. (2005). Budidaya tanaman sayuran dengan sistem hidroponik. Bandung: Balai Penelitian Tanaman Sayuran.

Saenong, M. S. (2016). Tumbuhan Indonesia potensial sebagai insektisida nabati untuk mengendalikan hama kumbang bubuk jagung (Sitophilus Spp.). Jurnal Penelitian dan Pengembangan Pertanian, 35(3), 131-142.

Samsudin, H. (2008). Pengendalian hama dengan insektisida botani. Jakarta: Bumi Aksara.

Sudjarwo. (2011). Dinamika kelompok. Bandung: Mandar Maju.

Suhartini., Suryadarma, P., \& Budiwati, B. (2017). Pemanfaatan pestisida nabati pada pengendalian hama plutella xylostella tanaman sawi (Brassica juncea L.) menuju pertanian ramah lingkungan. Jurnal Sains Dasar, 6(1), 36-43.

Sukidjo. (2000). Tujuan dan khalayak sasaran pengabdian pada masyarakat. Aplikasia: Jurnal Aplikasi Ilmu-Ilmu Agama, 2(1), 62-78. 
Suryaningsih, E., \& Hadisoeganda, W. W. (2004). Pestisida botani untuk mengendalikan hama dan penyakit pada tanaman sayuran. Bandung: Balai Penelitian Tanaman Sayuran.

\section{Copyright and License}

This is an open access article distributed under the terms of the Creative Commons Attribution 4.0 International License, which permits unrestricted use, distribution, and reproduction in any medium, provided the original work is properly cited.

(C) 2020 Liliek Harianie, Shinta, Lila Biarrohmah, Lina Hidayatur Rohmah, Widya Maslahah.

Published by LP3M of Universitas Mathla'ul Anwar Banten in collaboration with the Asosiasi Jurnal Pengabdian Kepada Masyarakat (AJPKM) 